\title{
Generic Technology R\&D in Strategic Emerging Industries: Enterprise Cooperation or Government Funding
}

\author{
Hongmin Liu, Weiwei Liu*, Yichao Han \\ School of Economics and Management, Zhejiang University of Science and Technology \\ Hangzhou, Zhejiang 310023, China
}

\begin{abstract}
Industrial generic technology R\&D is the key to the development of strategic emerging industries. The enterprises need the cooperative $R \& D$ of industrial generic technology, and also have to face competition in product market, in another word, the characteristics of attraction and exclusion affect the enterprise cooperative $R \& D$, so the government involvement are critical. The paper is aimed at the problem of the choice of strategic emerging industries: enterprise cooperation or government funding with the generic technology $R \& D$ by building analysis model, studies the characteristics of attractor and repeller. The government should take flexible fund strategy based on the characteristics of generic technology in strategic emerging industries, the whole competition situation of industry and the strength characteristics of key enterprises.
\end{abstract}

Keywords-Strategic emerging industries; Generic technology $R \& D ;$ cooperative $R \& D ;$ Enterprise cooperation; Government funding

\section{INTRODUCTION}

Strategic emerging industries are the industries which are related to the national economy overall situation, and may become the dominant or pillar industries (Forbes, 2011; Lin \& Hsieh, 2014 [1-2]. Industrial generic technology is widely used in several fields and produces a profound effect, so it is the technology in the forefront of competition [3].

Strategic emerging Industrial generic technology is not only big investment in high-risk, but also has significant knowledge spillovers. Generic technology $R \& D$ is typical public technology products. The public technology products have two development models of government-led and market-drive, but they have defects [4].

Governance and innovation of emerging industries is a big challenge (Stilgoe, J. et al., 2013; Buenstorf et al., 2015) [5-6] Li, G.J. (2007), academician of China Engineering Academy, holds that the intermediate link (namely industrial generic technology) of the innovation system appears vacancy. Projects of National Natural Science Foundation of China and "973" plan are mainly for basic research investment. The venture capital and enterprise investment are mainly aimed at product development. Therefore, the industrial generic technology research and technology transfer become the weakest link of technology innovation chain in China [7]. As shown in Fig.1.

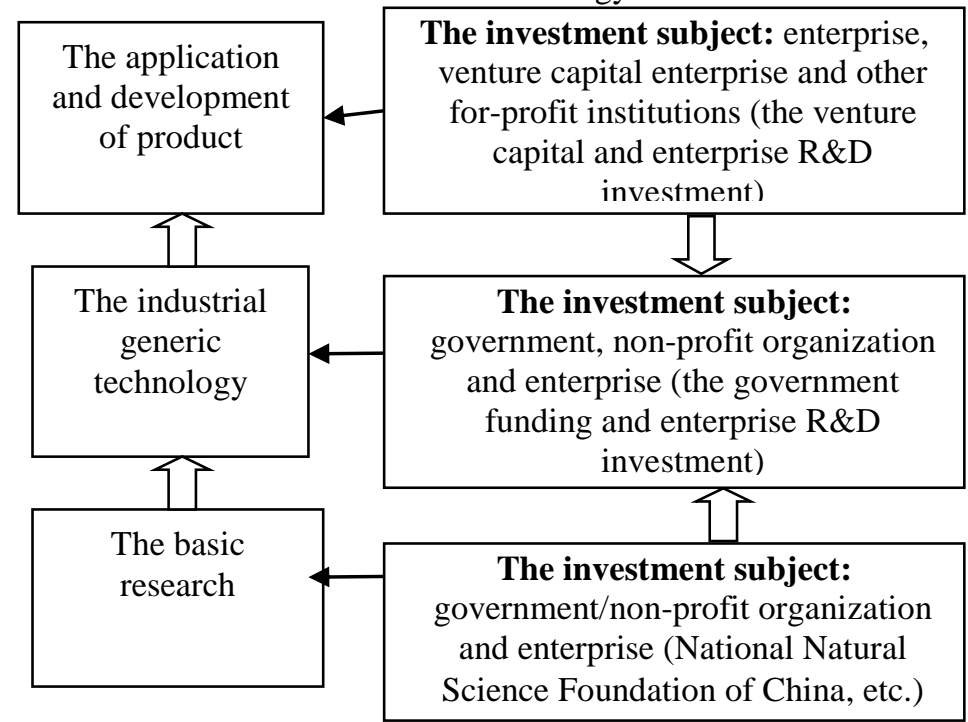

Fig. 1. The Technical Type and Investment Subject 


\section{LITERATURE REVIEW}

Strategic emerging industry is the combination of the strategic industry and emerging industry. There are two aspects. First, relating to the current evaluation of the policy system of China's strategic emerging industries, Liu (2011) point out that bull management and lack of coordination is an urgent problem [8]. Second, Yingming Li (2008) [9] indicated that policy combination is the focus of policy adjustment.

Gregory Tassey (1991; 1992) [10-1] has carried out the generic technology research earlier, however it falls behind in China. M.J., Ma (2005) [12] holds that the research mainly comes from the summary of policy practice instead of the theoretical analysis.

Scholars in China have studied the role of government in industrial generic technology development from different aspects. Wu (2003) [13] consider that the original intention of Institutional reform in the industrial sector is to thoroughly solve the communication difficultly of technology and economy, but the transformation of industry scientific research institution will bring a phenomenon that nobody to research industrial generic technology. Tang (2005) [14] has proposed an extension and application plan of national generic and public welfare technology... Li (2005) [15] has discussed the government problem of market and organization failure in process of generic technology supply.

Now, more and more enterprises have started to develop the industrial generic technology by cooperative, this is the demand of technology convergence. Technology convergence is a means of technological innovation, capability of enterprise have significant influence on different patterns(technology trade, technological alliance, mergers and acquisitions etc.) for company, although the influence is not identical[16]. The characteristics of cooperative $R \& D$ include: avoiding duplicated $R \& D$ in order to save costs, sharing resources and high collaboration of technology to break through the key technology, and the scale input of R\&D funds to break through the bottleneck (Vonortas, 1997; Tao\&Wu, 1997; Kline, 2000) [17-19]. Nowadays, cooperative R\&D has become an important pattern of enterprises technology innovation and product innovation management [20]. But research focuses on policy support and industrial planning, and research on generic technology R \& D model is rare. Research on the issue of public-private partnerships also focused on the cooperative utility efficiency, innovation incentive and risk sharing, etc. [21]

The enterprises need the cooperative $R \& D$ of industrial generic technology, and also have to face competition in the product market, in another word, the characteristics of attraction and exclusion affect the enterprise cooperative R\&D, so the government involvement are critical.

This study intends to consider the features of generic technology $R \& D$ and determine the relationship between enterprise cooperation and government funding of strategic emerging industries by building model.

\section{ANALYSIS MODEL}

Assuming there have duopoly enterprises $\mathrm{A}$ and $\mathrm{B}$ in strategic emerging industry, they plan to develop the industrial generic technology and conduct commercial development in order to form a commercial product. Sharing related revenues according to the respective market. Assume the market revenue is constant, and the market annual revenue alters with product life cycle curve. In general, market annual revenue function of new product is $\mathrm{M}$, which has been shown in Fig.2 (the cycle curve of product in each field is different, but it doesn't affect the results). When the new product puts into market, the life cycle of product begins until the product is completely replaced.

The R\&D ability of enterprise determines the R\&D time of technology, thus directly affects the time of subsequent commercial product into market. The R\&D ability of enterprise is $\mathrm{R}$, (including technical experts, experiment equipments and other factors), enterprise with higher $R \& D$ ability firstly launches the new product, therefore, the time of monopolizing market benefits will be longer. Setting the time for product into market is QT and it is the function of enterprise R\&D ability R. As shown in Fig.2, the role of QT in launching new products shows a marginal decrease with the increase of R\&D ability.

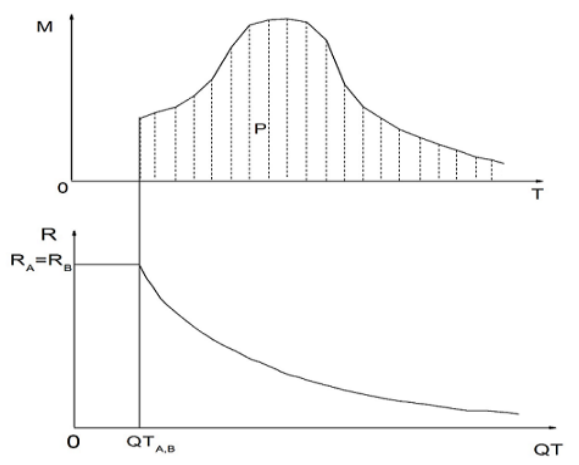

Fig. 2. The time function for product into market (QT) and the market revenue function $(\mathrm{M})$

When $\mathrm{T}=\mathrm{QT} \mathrm{T}_{\mathrm{A}}, \mathrm{B}$, the two enterprises simultaneously develop generic technology and successfully launch subsequent commercial product, the incomes for enterprise A and $\mathrm{B}$ are as follows:

SA and SB mean the market share of enterprise A and B, which is determined by the marketing ability of enterprise channel and brand. TF means the end moment of technology life cycle. $\mathrm{CA}$ and $\mathrm{CB}$ mean the $\mathrm{R} \& \mathrm{D}$ costs for enterprise $\mathrm{A}$ and $\mathrm{B}$.

Because of good technology and quickness of thought, the enterprise of higher R\&D ability costs lower than the weaker enterprise, therefore

$$
\text { When } R_{i}>R_{j}, C_{i}<C_{j}(i, j=A, B . i \neq j)
$$


If enterprise develops the industrial generic technology, it needs the R\&D funds as well as R\&D ability. Setting enterprise funds used in generic technology development is $\mathrm{Z}$, the necessarycondition for enterprise to conduct independent development is as follows:

$$
\begin{aligned}
& \mathrm{Z}_{\mathrm{i}}>\mathrm{C}_{\mathrm{i}}(\mathrm{i}=\mathrm{A}, \mathrm{B}) \\
& \mathrm{P}_{\mathrm{i}}>\mathrm{C}_{\mathrm{i}}(\mathrm{i}=\mathrm{A}, \mathrm{B})
\end{aligned}
$$

For industrial generic technology, the strategy space of enterprise includes no-feasance, independent and cooperative R\&D. For cooperative R\&D, partners would get technology at the end of R\&D project and they usually put into same funds. Otherwise, the cooperative will be difficult.
The cooperative $R \& D$ willingness between enterprises in industrial generic technology is mainly affected by attractor (the $\mathrm{R} \& \mathrm{D}$ investment, $\mathrm{R} \& \mathrm{D}$ risk and complementary of technical resources) and repeller (the differences in the marketing channel and brand and the superior characteristics of forerunner), as shown in Fig.3. To simplify the analysis model, the risk and externality of industrial generic technology $\mathrm{R} \& \mathrm{D}$ are not considered in this paper.

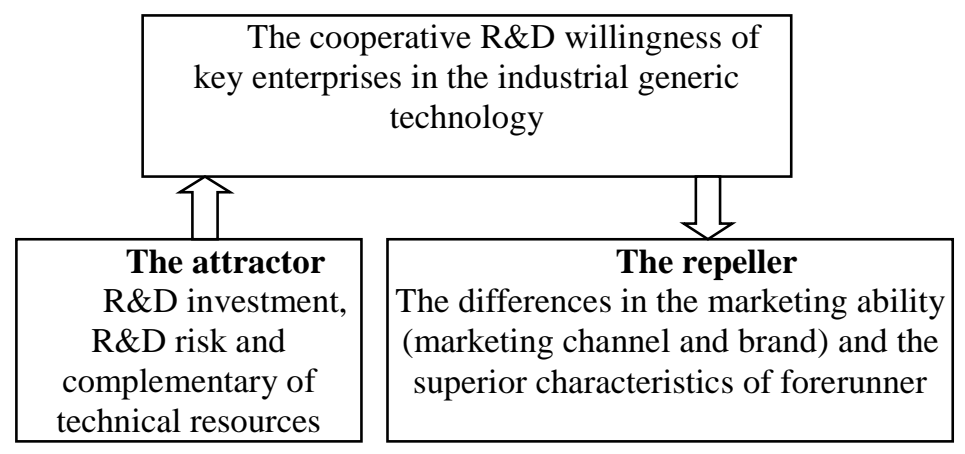

Fig. 3. Factors affecting the cooperative R\&D willingness between enterprises in industrial generic technology

\section{A. The feasibility analysis of enterprise cooperative $R \& D$ when key enterprises have similar $R \& D$ ability and independent $R \& D$ condition}

As shown in Fig. $1, \mathrm{R}_{\mathrm{A}}=\mathrm{R}_{\mathrm{B}}$ means that enterprise $\mathrm{A}$ and $\mathrm{B}$ have developed a new technology simultaneously when $\mathrm{T}=$ $\mathrm{QT}_{\mathrm{A}, \mathrm{B}}$.

When enterprise A and B conduct independent R\&D, their incomes are as follows:

$$
\mathrm{P}_{\mathrm{i}}^{\mathrm{D}}=\mathrm{S}_{\mathrm{i}} * \mathrm{P}-\mathrm{C}_{\mathrm{i}} \quad(\mathrm{i}=\mathrm{A}, \mathrm{B})
$$

When enterprise $\mathrm{A}$ and $\mathrm{B}$ conduct cooperative $\mathrm{R} \& \mathrm{D}$, their incomes are as follows:

$$
\mathrm{P}_{\mathrm{i}}{ }^{\mathrm{G}}=\mathrm{S}_{\mathrm{i}} * \mathrm{P}-\mathrm{C}_{\mathrm{i}} / 2 \quad(\mathrm{i}=\mathrm{A}, \mathrm{B})
$$

For $\mathrm{P}_{\mathrm{i}}^{\mathrm{G}}>\mathrm{P}_{\mathrm{i}}^{\mathrm{D}}$, whether $\mathrm{SA}$ and $\mathrm{SB}$ are equal or not, both have incentive to participate in cooperative $R \& D$. So the role of government is not to provide fund, but actively coordinate enterprises to save costs and improve the industry competitive advantage.

\section{B. The feasibility analysis of enterprise cooperative $R \& D$ when key enterprises have unequal $R \& D$ ability but independent $R \& D$ condition}

As shown in Fig.4, assuming $R_{A}>R_{B}$, enterprise $A$ develops the new technology when $\mathrm{T}=\mathrm{QT}_{\mathrm{A}}$, and its $\mathrm{R} \& \mathrm{D}$ ability is better than enterprise $\mathrm{B}$ which could develop new technology when $\mathrm{T}=\mathrm{QT}_{\mathrm{B}}$.

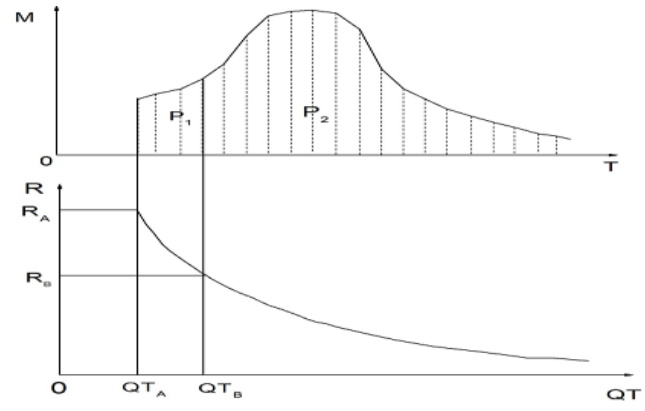

Fig. 4. When $R_{A}>R_{B}$, the time of launching new products and corresponding market revenue for enterprise $\mathrm{A}$ and $\mathrm{B}$.

In such cases, when enterprise $A$ and $B$ conduct $R \& D$ activities individually, their incomes are as follows:

$$
\begin{gathered}
\mathrm{P}_{\mathrm{A}}^{\mathrm{D}}=\mathrm{P}_{1}+\mathrm{S}_{\mathrm{A}} * \mathrm{P}_{2}-\mathrm{C}_{\mathrm{A}} \\
\mathrm{P}_{\mathrm{B}}{ }^{\mathrm{D}}=\mathrm{S}_{\mathrm{B}} * \mathrm{P}_{2}-\mathrm{C}_{\mathrm{B}}
\end{gathered}
$$

In which, $\mathrm{P}_{1}$ means market gains in the stage of $\mathrm{T}=\mathrm{QT}_{\mathrm{A}}$ and $\mathrm{QT}_{\mathrm{B}}, \mathrm{P}_{2}$ means market gains after $\mathrm{T}=\mathrm{QT}_{\mathrm{B}}$, and $\mathrm{P}_{2}$ is divided by enterprise $\mathrm{A}$ and $\mathrm{B}$ according to their market share. For $\mathrm{P}_{1}$, it is individually obtained by enterprise $\mathrm{A}$ with characteristics of monopoly, which derived from the advantages of forerunner, because the market forerunner could build resource advantage in the market, and could get more tangible and intangible assets than others, including technology knowledge, brands and trademarks (Liberman\&Montgomery, 1988) [22]. 
In this case, when enterprise A and B conduct cooperative $\mathrm{R} \& \mathrm{D}$, their income are as follows:

$$
\begin{aligned}
P_{A}{ }^{G}=S_{A} * P-C_{A} / 2 \\
P_{B}{ }^{G}=S_{B} * P-C_{A} / 2
\end{aligned}
$$

If the cooperative $R \& D$ is the dominant strategy of both sides, it requires that:

$$
\begin{gathered}
\mathrm{P}_{\mathrm{A}}{ }^{\mathrm{G}}-\mathrm{P}_{\mathrm{A}}{ }^{\mathrm{D}}=\mathrm{C}_{\mathrm{A}} / 2-\mathrm{S}_{\mathrm{B}} * \mathrm{P}_{1}>0 \\
\mathrm{P}_{\mathrm{B}}{ }^{\mathrm{G}}-\mathrm{P}_{\mathrm{B}}{ }^{\mathrm{D}}=\mathrm{S}_{\mathrm{B}} * \mathrm{P}_{1}+\mathrm{C}_{\mathrm{B}}-\mathrm{C}_{\mathrm{A}} / 2>0
\end{gathered}
$$

To make enterprise $A$ have incentive for cooperative $R \& D$, it demands $\mathrm{CA} / 2-\mathrm{SB} * \mathrm{P} 1>0$, when $\mathrm{CA}$ keeps invariant. the greater the $\mathrm{SB}$, and the smaller the $\mathrm{P} 1$, which means when the R\&D abilities of enterprise B and A are extremely close, enterprise A could be motivated to conduct cooperative R\&D with B. Instead, when both SB and P1 are smaller, enterprise A has incentive for cooperative $R \& D$, which becomes weaker when the increase of marketing ability of B. For B, which becomes weaker with the increase of marketing ability of enterprise $B$. For enterprise $B, C_{B}>C_{A}$ while $R_{A}>R_{B}$, and conditions in the equality (12) are met, therefore, enterprise $\mathrm{B}$ always has enthusiasm of cooperative R\&D with $\mathrm{A}$.

In this case, the government could take the following strategies: (1) when enterprises have big gap between marketing ability, but similar R\&D ability, the government should actively conduct cooperative R\&D. (2) when enterprises have big gap between marketing and $R \& D$ ability, the government should provide fund when $\mathrm{M}>\mathrm{SB} * \mathrm{P} 1-\mathrm{CA} / 2$.

\section{The feasibility analysis of enterprise cooperative $R \& D$ when one party is unable to conduct independent $R \& D$ while the other side has the independent $R \& D$ ability}

Assuming $\mathrm{P}_{B}<\mathrm{C}_{B}$ and $\mathrm{R}_{B}<\mathrm{R}_{A}$, when enterprise $B$ conducts independent $R \& D$, the market returns are less than R\&D costs, and its R\&D ability is weaker than enterprise A.

In this case, if the enterprise A conducts independent $R \& D$, it will monopolize all market gains:

$$
\mathrm{P}_{\mathrm{A}} \mathrm{D}=\mathrm{P}-\mathrm{C}_{\mathrm{A}}
$$

To make enterprises A has incentive for cooperative $R \& D$, it requires

$$
\mathrm{P}_{\mathrm{A}} \mathrm{G}>\mathrm{P}_{\mathrm{A}}^{\mathrm{D}}
$$

That is $\mathrm{C}_{\mathrm{A}} / 2-\left(1-\mathrm{S}_{\mathrm{A}}\right) * \mathrm{P}>0$, which means that the industrial generic technology requires large amounts of R\&D investment and strong marketing ability for enterprise A, only in this situation, enterprise $\mathrm{A}$ has motivation for cooperative $R \& D$ with enterprise $B$, otherwise, enterprise $A$ has no interests in cooperation with enterprise B.

In this situation, it is difficult for government to make two enterprises conduct cooperation only through coordination, it needs to fund the cooperative $R \& D$ organization, and enterprises could effectively carry out cooperative $R \& D$ only when $\mathrm{M}>\left(1-\mathrm{S}_{\mathrm{A}}\right) * \mathrm{P}-\mathrm{C}_{\mathrm{A}} / 2$.
D. The feasibility analysis of enterprise cooperative $R \& D$ when the $R \& D$ cost is extremely high and key enterprises can't afford to rely on their own strength

In this case, $\mathrm{Z}_{\mathrm{A}}<\mathrm{C}_{\mathrm{A}}, \mathrm{Z}_{\mathrm{B}}<\mathrm{C}_{\mathrm{B}}$, and $\mathrm{Z}_{\mathrm{A}}+\mathrm{Z}_{\mathrm{B}}<\mathrm{C}\left(\mathrm{C}=\min \left(\mathrm{C}_{\mathrm{A}}\right.\right.$, $\left.C_{B}\right)$ ), both of enterprises have cooperative $R \& D$ incentives, but high R\&D costs make enterprises not rely on their own strength to cooperate, and the government should fund the cooperative $\mathrm{R} \& \mathrm{D}$ organization through project establishment, and the amount of fund is as follows:

$$
\mathrm{M}>\max \left(\mathrm{C} / 2-\mathrm{S}_{\mathrm{A}} * \mathrm{P}, \mathrm{C} / 2-\mathrm{S}_{\mathrm{B}} * \mathrm{P}\right)
$$

\section{CONCLUSIONS AND POLICY IMPLICATIONS}

Through the generic technology $R \& D$ in strategic emerging industries, it can be drown with three conclusions in the paper:

(1) When key enterprises in strategic emerging industries have similar R\&D ability and independent R\&D condition, the government should actively coordinate the two enterprises to conduct cooperative R\&D.

(2) When enterprises have unequal R\&D ability but independent $R \& D$ condition, the financial aid policy of government should be planned according to the characteristics of industry competition and strength of enterprises.

(3) When the R\&D cost is extremely high, and enterprises can't rely on their own strength, the R\&D fund from government becomes the key factor which determines enterprise cooperative $R \& D$.

Through the above conclusions, it can be drawn from two policy implications:

(1) In order to encourage enterprises to cooperate research and improve the efficiency of government, the government should take flexible fund strategy based on the characteristics of generic technology in strategic emerging industries, the whole competition situation of industry and the strength characteristics of key enterprises.

(2) To generic technology $R \& D$ in strategic emerging industries, the strategy not only is affected by technology and the competitive, but also the related coordination of government. In order to encourage enterprise cooperative $\mathrm{R} \& \mathrm{D}$, the strategy requires government coordination of those spaces without fund, low and high amount of fund. The higher $\mathrm{R} \& \mathrm{D}$ ability of enterprise, the $\mathrm{R} \& \mathrm{D}$ funds is more, the cooperative $R \& D$ incentive is higher, the government fund is smaller, and the intervention degree is lower; contrarily, the funds is more, the intervention degree is deeper.

\section{ACKNOWLEDGMENT}

Project supported by the National Social Science Foundation of China (NO.16BGL161). 


\section{REFERENCES}

[1] Forbes D P,Kirsch D A. The study of emerging industries: Recognizing and responding to some central problems [J]. Journal of Business Venturing, 2011,26(5): 589 - 602.

[2] Lin F R., Hsieh P S. Analyzing the sustainability of a newly developed service: An activity theory perspective [J]. Technovation, 2014, 34(2): 113-125.

[3] Tassey G. Underinvestment in public good technologies [J]. Journal of Technology Transfer, 2004,30(1/2): 89-113.

[4] Tassey G. Standardization in technology - based markets [J]. Research Policy, 2000, 29(4) :587-602.

[5] Buenstorf G., Fritsch M., Medrano L. F. Regional Knowledge, Organizational Capabilities and the Emergence of the West German Laser Systems Industry, 1975-2005[J]. Regional Studies, 2015, 49 (1):59-75.

[6] Stilgoe J, Owen R, Macnaghten P. Developing a framework for responsible innovation [J]. Research Policy,2013,42(9):1568-1580.

[7] Li, G.J., 2007. To strengthen the pre-competitive cooperation and vigorously develop industrial generic technology. Forum on science and technology in China, 2:12-15.

[8] Liu F., Simon D F, Sun Y, et al. China's innovation policies: Evolution, institutional structure and trajectory [J]. Research Policy, 2011, 40(7): 917-931

[9] Li Y. The economic efficiency of public policy and the regional innovation service platform construction [J]. Science of Science and Management of S\&T, 2008, (11):49-56. (in Chinese)

[10] Tassey G. The Functions of Technology Infrastructure in a Competitive Economy, Research Policy, 1991(20): 345-361.

[11] Tassey G. Technology infrastructure and competitive position, Norwell, MA: Kluwer Academic Publishers, 1992.
[12] Ma M.J., "The connotation and evaluation standard of generic technology", The Development Research Center of the State Council (DRC), vol.153, pp.102-118, 2004.

[13] Wu Guisheng, Li Jizhen, "The supply system study of the industrial generic technology", Science Technology and Engineering, no. 4, pp.3842, 2003.

[14] Tang Wuxiang, Zhou Feiyue, "Cheng Guizhi. Study on the Spread and Application Plan of Important Commonness and Commonweal Technology", Science OF science and management of S.\& T., no. 10, pp 26-32, 2005.

[15] Li Jizhen, "Study on the role of government in industrial generic technology development", Technical and Economic, no. 9, pp.12-18, 2005.

[16] Ping Li, Fengxian Yang, "Capability of Enterprise: How to Choose Patterns of Technology Convergence for Firms", AISS, vol. 5, no. 5, pp. $509 \sim 518,2013$

[17] Vonortas N S. "Research joint ventures in the US", Research Policy, vol. 26, no. 4, pp.577-595, 1997.

[18] Tao Z.G, Wu C.Q, "On the organization of cooperative research and development: theory and evidence", International Journal of Industrial Organization, vol. 15, no. 5, pp.573-596, 1997.

[19] Kline J J., "Research joint ventures and the cost paradox", International Journal of Industrial Organization, vol. 18, no. 7, pp.1049-1065, 2000.

[20] Jun Y, Xuan W, Liu Z.B, "Research on Product Innovation and Design Management", AISS, vol. 5, no. 4, pp. 149 155, 2013.

[21] Daechang K. Optimal contracts of public - private partnerships with demand risk [J]. Seoul Journal of Economics, 2012,25(3) :255-277.

[22] Liberman M, Montgomery D B, "First-mover Advantages Strategic", Management Journal, vol. 19, no. 9, pp.41-58, 1988. 